\title{
TEXTUAL ANALYSIS ON CELEBRITY NEWS IN THE ONLINE MEDIA
}

\author{
Agwin Degaf, I Dewa Putu Wijana, Soepomo Poedjosoedarmo
}

\author{
agwindegaf10@gmail.com \\ Gadjah Mada University \\ Yogyakarta, DIY, Indonesia
}

\begin{abstract}
This research examines online media related to the cases of Indonesian celebrities using a critical discourse analysis approach. It aims to explain the textual strategies used by the online press upon reporting the facts. The textual strategy focuses on the selection of precise vocabulary and the use of specific grammar. The data are collected through reading and note taking techniques on news texts in the online media, liputan6.com, and kapanlagi.com, with topics such as the divorce of Marshanda, Asmirandah interfaith marriage, and the case of celebrity prostitution. The current descriptive qualitative research employs critical discourse analysis proposed by van Dijk which generally believes that media always contains interests and partisanships. Therefore, they tend to provide a positive picture of themselves/groups (positive selfpresentation) and negative images about others (negative other presentation). The map can be analyzed through the way the media use the diction and build specific sentences inside the news. The result shows that the media uses the vocabulary such as mothers who have an affair, women who cannot be emulated, presumptuous women, a liar man, no longer Muslim when reporting on the case of Marshanda's divorce, and Asmirandah's interfaith marriage. Furthermore, the researcher finds the use of passivation, abstraction, categorization, identification, and anonymity strategies in grammar.
\end{abstract}

Keywords: critical discourse analysis, textual analysis, celebrity news, online media.

\section{INTRODUCTION}

One type of favorite news in Indonesian mass media is infotainment or news related to Indonesian celebrities. Almost all TV stations in Indonesia present a program providing information regarding the personal life of stars. Not only television, printed, and online media also have specific pages for celebrity news. Usually, the chosen report to be presented is considered an issue that they expect to be the public's attention. Thus, considering that almost all media have a page to report the celebrity life, infotainment is a critical issue that deserves and is worth saying.

Detik.com (Saturday, 05/06/2010), in the article entitled "Study: The Fastest Growth of Internet in Indonesia," wrote if Indonesian users managed to reach as many as $48 \%$ of active internet users over Southeast Asia, based on the result of the Net Index Study in collaboration with Yahoo. The number increases by $26 \%$ compared to 2009 . It is due to an increase in internet users via cellphones or mobile internet and the trend to access online media. The results of the study highlight three significant changes: firstly, the fact that users in the region are now consuming more online media to find out the latest information; secondly, the increasing users involving in online social media in both contribution and distribution of the data; lastly, the growing consumption of users over the content of entertainment, gossip and games. The fact that internet users accessing the gossip page are the 3rd largest is one of the reasons why research on artist-related news is exciting to do.

News regarding the gossip of celebrities also had become the main headline in several Indonesian mass media. It proves that the life of the entertainment industry workers is still 
something highly awaited by society. For example, the news reporting a nasty video whose actor is deemed to be an artist in 2010 became the main headline in almost all media, both printed and electronic. Some even thought that the news was intentionally inflated to neutralize news about cases of some political elites (Irsyadi, 2019: 203). The story about the nasty video like Ariel, Luna Maya, and Cut Tari seems to be set as an opinion diversion towards the trending issues of Susno Duaji and Century Gate that they no longer appear on the screen, and the public soon forgot them. When news about the nasty video between Ariel, Luna, and Cut Tari directly becomes public gossip, it leads to a discourse. Lull (1998: 225 in Sobur, 2012: 11) states that discourse is the way objects or ideas are discussed open to the public, that it causes particular understanding widely spread. Therefore, a report on celebrities becomes interesting to study using a discourse analysis approach.

Discourse analysis (DA) in this research is an analysis of discourse coming up as a reaction to pure linguistics, which cannot reveal the nature of language entirely (Darma, 2009: 15). In this case, DA experts try to provide alternatives for understanding the nature of the language. Stubbs (1989:1) argues that DA is a study that examines and analyzes the language naturally used, either in the spoken or written form, such as the use of language in daily communication. DA is commonly used to find the meaning of discourse, which is the same, or at least very close to the purpose intended by the speaker in spoken discourse, or by the writer is written one.

According to Hall (1982: 67), meaning does not depend on the structure of the definition itself, but it refers to the practice. The essence is a social product and method. Mass media does not reproduce but determines a reality based on the chosen vocabulary use. Meaning is not a simple belief as a language reproduction, but a social conflict and struggle for winning a discourse (Rahayu et al., 2015: 25). Concerning meaning, media is seen as a forum for all kinds of the group with a different point of views to meet. Each party tries to show up their base interpretation, claim, and argument (Eriyanto, 2009:38). The target is to let society accept his opinion more.
From the statement above, the researcher decides to take several online news focusing on which engage in celebrity's issues about some topics, especially marriage, divorce, accident, and some other criminal news as the data source to be analyzed with discourse analysis approach under Teun A. Van Dijk theory. Van Dijk captures three dimensions, text, social cognition, and social context. The researcher only analyzes the first dimension, texts. The purpose of this study is to examine how the National Online Media portrays some celebrity cases through a Critical Discourse Analysis of a number of its articles. The main question at issue is: How is national online media reports news about celebrities in their items? This central question is illuminated through sub-questions: How the grammar and specifically chosen vocabularies (lexicalization) bring an implication and ideology to the object of the news?

\section{Mass Media and Language in the Critical Discourse Analysis Perspective}

Language, as a discourse tool, plays a vital role in transforming a certain kind of subject, theme, and public opinion. Communication plays the function of representation because discourse is compiled from three language orders, which is commonly called "discursive structures" in Linguistics term. It determines people's perspective in seeing an object (Van Dijk, 2004).

An object or phenomenon can be transformed into a different perception because the altered use of language structure upon defining an object or event creates different understandings, which leads to separate actions too. The function of language structure is to produce discourse, to form a point of view, and to influence society's attitude, and this is what a mass media has played over (Barrat, 1994: 52).

Media is one of the most critical agents in defining a group through language from the news which is continuously spread. Unconsciously, media already shapes an understanding and awareness of society's mind about a thing (Eriyanto, 2009: 172) by using certain words or sentences and creates a specific image. A group or phenomenon can be reported and interpreted from media texts based on their tendency, wish, and the writer's 
purpose/media owner. Richardson (2007: 47) argues that analyzing media production through words is the early start to analyze text and discourse; it proves that language in media can deliver a definite meaning because it influences people to believe and controls over the reader's mind related to a particular case. An object or phenomenon can be transformed into a different perception because the altered use of language structure upon defining an object or event creates different understandings, which leads to separate actions too. The function of language structure is to produce discourse, to form a point of view, and to influence society's attitude, and this is what a mass media has played over (Barrat, 1994: 52).

Besides, when it comes to lexical choice, a word or sentence construction is more likely used rather than a word or other sentences through contextual reason, such as peoples' opinion towards an individual or a group (Dijk, 2009: 40). Media is a space where one discourse (prior discourse) proposes a claim of truth through language modification, while another discussion makes criticism or attack (counter-discourse). It is replied by the first discourse using defense (apologetic discourse), or might be attacked back (countercounter discourse) (Rahardjo, 2007: 74). Therefore, a media should not only be understood through the news content, but also the language construction. Thus the reader can understand the news (on the surface) and what is hidden behind the texts.

\section{The previous Study Related to Critical Discourse Analysis on Online Media}

Notable previous research has been examined regarding the use of language in discourse analysis an online media. Kabgani (2013) researched about Muslimah representation towards non-Muslim media. She wrote in the framework of critical discourse analysis (CDA) Van Leeuwen (1996) to analyze an article from English newspaper broadsheet, the Guardian. The focus of the research is about the Muslim perspective toward non-Muslim media, and the reason why she takes English news is that Europeans are commonly judged undemocratic to the other ethnic and race. The reflection of this behavior can be observed through their media. She found that Muslimah is described as an active actor in their circumstances. In other words, Muslimah is depicted as entirely truthful to their belief and an independent woman who is looking for their resurgence and identity.

Austin (2014) then analyzed drug abuse among American celebrities using a critical discourse analysis approach. The research data was taken from The New York Times online from December 2012 to December 2013. Critical discourse analysis approach used by the researcher to determine the dominant discourse in news articles related to substance abuse by celebrities. From this research, it is known that the news of substance abuse by stars in the New York Times presented a limited basis. The report only focuses on the individual side and mere moral problems. Communication in the media excludes information on substance abuse as a serious social problem and the danger to medical conditions. Also, recovery from illicit substance abuse is presented as a personal choice from the celebrity. It is ordinary and customary, so readers seem to be led to think that substance abuse among stars is a common thing, and can be easily cured.

Another previous study conducted by Soares (2017) analyzes on two front pages of Super Noticia, a popular newspaper from Brazil. The researcher did so to identify the relationship between linguistic choices and specific images with ideology, hegemony, and persuasion strategies used by the newspaper's producers. Through critical discourse analysis, he found the use of discursive strategies such as democratization and technologization as one of the persuasion strategies of the press. Besides, illustrated images on the front page of newspapers are also used to maintain practices and ideologies related to gender, preservation of hegemony, and legitimacy related to certain stereotypes.

Another prominent study is done by Susanto and Zhang (2017), who concentrate on cyber media coverage related to interfaith marriages in Indonesia. This study chose the Norman Fairclough model of critical discourse analysis as an analytical knife. The researchers analyzed three cyber media, namely; Republika Online, Kompas.com, and Sinarharapan.co from September to December 2014. One of the main objectives is to find out which media tends to support diversity, discourse practices, and sociocultural practices. Their results show 
that Islamic-oriented media, such as Republika Online, tend to reject movements that want to legalize interfaith marriage while more secular online media, such as Kompas.com with an independent ethos of transcendental humanism, are more inclined to support rights for couples of different religions. Meanwhile, Sinarharapan.co, which is oriented towards Christianity, tends to ignore this problem, as if it is something that is not important to their readers.

Most of the previous researches use critical paradigm as the basis of analysis. The critical paradigm appears as an answer to the sensitivity of positivism and interpretivism paradigm towards the process of production and meaning reproduction. The two paradigms ignore the dimension of power and the importance of discourse practice. It is different from some researches above, which uses the theory of Halliday, van Leeuwen and Fairclough's model of Critical Discourse Analysis. The researcher in this study employs Van Dijk's theory. Nevertheless, this research also focuses on topics related to divorce, interfaith marriages, and cases of prostitution involving Indonesian celebrities.

\section{METHOD}

Generally, there are two kinds of research, quantitative and qualitative. Miles and Huberman (1994: 1) states that qualitative research is commonly provided in the form of words and note number. In this study, the researcher uses a qualitative research methodology. Bogdan and Biklen (1986) explain that qualitative methodology is a research procedure that produces descriptive data of observable written or spoken words and behavior. This research attempts to describe the phenomenon of human life related explicitly to words, utterances, and dialog as the primary data. It will be complicated to measure the data using a quantitative method. Besides, It discusses the data using critical discourse analysis. The paradigm of criticism focuses more on the absence of interest and power relation in the production and reproduction of meaning over the discourse. Also, an individual cannot be separated from ideological interest and power relations as either a subject or object in the practice of discourse (Rosidi, 2007: 9). The data are taken from text in an online media portal (kapanlagi. com and liputan6.com) using literaryreview.

The data sources of this research are news related to celebrities in online media portal such as divorce, marriage, and prostitution. In order to answer the research problem, it employs a matching method, a research method with outer determination tools either as a part of the relevant language or not (Kesuma, 2007: 47). Based on the research problem, the researcher collects the data from the portal of online media, which has a unique column to discuss celebrity. The researcher then reduces the news to get relevancy between the data and research problem. In van Dijk's theory, this research focuses on the textual strategy used by online media in writing news about actor/event related to Indonesian celebrity. It aims to inquire in-depth analysis and understanding of the discourse of entertainment news using a critical discourse analysis approach.

\section{DISCUSSION}

In this part, the researcher displays the smallest structure of text/microstructure (Dijk, 1997), used by online media in writing Indonesian entertainment news. The microstructure is the meaning of discourse observable from the word choice and sentence used by online media in reporting news. The textual strategy used by kapanlagi.com and liputan6.com is classified into two categories; word choice and grammar.

\section{Word Choice (Lexicalization)}

Lexicalization is a textual strategy in choosing words from various possibilities of the available words. Additionally, the lexicon is a language component that accommodates all information related to the meaning and word use within a language. Richardson (2007: 47) believes that the analysis of particular words used by media is the starting point to analyze text or discourse. Word choice of a media is consciously used, and it shows how the media take the point of view towards reality. Similar reality can be reported in different ways depending on the interest and take the side of the media. Often a word choice is linked with text producer's point of view, with some other view - it is an $u s$ versus them situation (Allan \& Burridge 
(2006: 49). In the context of this research, celebrities who are considered as part of "us" will be reported using positive words, whereas those who are considered as a "them" will be reported with negative words.

An example of this strategy can be seen from the news on November 27, 2013, related to the polemic of Asmirandah's marriage. Kapanlagi.com wrote news titled "Jonas Tak Lagi Muslim, Jadi Alasan Gugatan Batal Nikah Asmirandah," meanwhile, liputan6.com wrote, "Jonas Bohong Jadi Mualaf, Alasan Asmirandah Batalkan Pernikahan." There are some differences in using the lexical strategy found on the news title. A language always provides classification. Inevitable reality can be categorized in a particular way and differentiated from others. The data above can be classified as follows in the following table:

Table 1. The classification of word choice in the news about Asmirandah interfaith marriage.

\begin{tabular}{ll}
\hline $\begin{array}{l}\text { Classification } \\
\text { (Pro- Asmirandah) }\end{array}$ & $\begin{array}{l}\text { Classification } \\
\text { (Anti-Asmirandah) }\end{array}$ \\
\hline $\begin{array}{l}\text { Jonas bohong jadi } \\
\text { muallaf } \quad \text { Tak lagi Muslim (no } \\
\text { pretends to be } \\
\text { muallaf) }\end{array}$ & \\
\hline $\begin{array}{l}\text { Alasan ... (making } \\
\text { reason ...) }\end{array}$ & $\begin{array}{l}\text { Jadi alasan ... } \\
\text { (become reason ...) }\end{array}$ \\
\hline $\begin{array}{l}\text { Batalkan } \\
\text { pernikahan (cancel } \\
\text { the marriage) }\end{array}$ & $\begin{array}{l}\text { Gugatan batal nikah } \\
\text { (marriage } \\
\text { cancelation claim) }\end{array}$ \\
\hline
\end{tabular}

The first component (tak lagi Muslim bohong jadi mualaf) can be observed that the word choice is more neutral, while the second one provides a more negative impression towards Jonas. Furthermore, the second component (jadi alasan - alasan), by adding "jadi" on the phrase, Asmirandah is represented as if she feigned an excuse to invalidate the marriage so that Jonas is described as the victim. On the other side, the second title conveys that Jonas's action to lie "bohong" causes Asmirandah to sue him to invalidate the marriage. In the first title, Asmiranda is represented into a negative impression, but decisive in the second one. Lastly, the use of gugatan in the third component (gugatan batal nikah - batalkan pernikahan) leads to a negative impression because gugatan means something already planned. It seems that Asmirandah has planned everything. Compared to the second title, the word "batalkan" means that the action is taken as the consequence of Jonas's lie to be a Muslim. It is called the cause-effect relation. In conclusion, the first media represents Jonas on the positive side and Asmirandah in the negative. The other media is the opposite.

Another example of a word choice strategy can be found in the news related to the divorce between Ben Kasyafani and Marshanda. One of the news on liputan6.com is written "Ben Kesal Marshanda Ajak Anak Saat Bertemu Selingkuhan" by having word choice such as bertemu selingkuhan to complete the issue of cheating in their marriage. The media has made specific classification and reality. The word used by the media heads the reader on how to understand reality. Marshanda is described as a mother who involves her daughter when doing lousy things, meeting other men (bertemu selingkuhan). Cheating is a wrong action, moreover having a kid involved. It the way media tries to direct the reader to see reality. It is supported by using another negative connotation word such as membongkar aib (exposing scandal), dan lancang (impudent). Implicitly, the media drives the reader to believe that it is reasonable when Ben (Marshanda's husband) gets mad due to her wife's disobedience. In their divorce, the public will consider Marshanda is guilty while Ben is on the contrary. In this context, a word does not only limit the readers' sight, but it also judges a particular actor/event. Marshanda is a mother who does cheating, a mother who cannot be a good role model, a woman exposing the scandal of the family, an impudent woman.

\section{Word choices' classification}

In a critical paradigm, language is seen as a classification system. Language performs the classification function, as a world view mediator. The significance of this classification can be seen from how a similar event can be realized using different vocabulary. Fowler et al. (1979) state that classification occurs because reality is so complex that people then simplify that reality. Classification provides an arena for controlling information and experience. For example, in the case of Asmirandah's marriage with Vanno. When Asmirandah's mother knew the fact that Vanno had returned to his previous religion, it could be said to be "lying", it could also be said as "not 
daring to be honest" (because religion is sensitive and personal, so Vanno has not dared to tell the truth to Asmirandah's mother). Here we can see how these words provide a classification of particular understandings of reality. Words such as Vanno are blasphemers, toying with religion, harm religious harmony, liar man, have forced us to see how reality should be understood. The classification means events must be seen on the one side, not the other.

Another example of vocabulary classification can be seen in cases of prostitution involving several Indonesian celebrities. In media coverage, the vocabulary that is widely used is menjual diri,psk artis, aksi prostitusi, and wanita bayaran. By giving such terms to name the case that wraps several female celebrities, the media has established classification and specific reality.

This vocabulary gives direction to the reader how reality should be understood. First, the female celebrities were the one who was guilty because they were actively involved and volunteered to work in the field of prostitution. Second, these words also limit the reader from seeing the case of the artist's prostitution merely as the fault of the woman who provides services and ignores the fact that prostitution can only be possible if there are two parties to the transaction. There was no question and omitted the facts about those who ordered sex services for these celebrities.

Lastly, let us look at the classification of vocabulary for reporting on the divorce of Marshanda and Ben Kasyafani. The vocabulary that often arises, causes Marshanda to be classified as a woman who has an affair, experiences mental disorders, disobedience, does not respect her husband, and so on. The vocabulary used by the media is not only "nonneutral" and does not describe reality, but also contains a judgment.

The vocabulary classification used by the media to describe Marshanda invites the readers to give a lousy assessment to her. Marshanda is portrayed as a woman, a wife, and a bad mother. The audience will sympathize with the man (Ben Kasyafani) and on the other hand, feel resentful with Marshanda's behavior. Classification is indeed able to make readers see an event on one side, not another. Words, then force the audience not only to understand reality but how reality must be understood.

\section{Grammar}

Grammar, according to van Dijk (1997), is closely related to sentence structure, which is a syntactic aspect related to logical thinking called the principle of causality. This causality logic is defined as subject arrangement (which explains) and predicate (which is explained) (Eriyanto, 2009: 251). The language setting here is not only a technical matter of syntactic accuracy but also a meaning formed by specific sentence structures. There are specific grammatical rules found in the news related to celebrities on several online media, including:

\section{Structure of Active/ Passive Sentence}

The use of active/passive sentences in critical discourse analysis is not only seen as a matter of grammar, and is not also considered as a product of journalists' unconsciousness when writing news (van Dijk, 2000). However, the form of sentences determines the meaning produced by the sentence. An active sentence emphasizes the subject or doer, while the passive sentence emphasizes the target of action or the action itself. Through the passive sentence structure, the doer can be hidden even removed from the text (van Dijk, 2003).

The researcher found a couple of news related to celebrity prostitution, which uses active-passive textual strategies. They are presented in the following table:

Table 2. The use of active-passive sentence in the news title.

\begin{tabular}{lll}
\hline Media & $\begin{array}{l}\text { Translated } \\
\text { Title }\end{array}$ & Original Title \\
\hline Liputan6.com & The Case of & Kasus Nikita \\
& Nikita Mirzani, & Mirzani, \\
& Ahmad Dhani & Ahmad Dhani \\
& Reported an & Polisikan \\
& Online Media. & Media Online. \\
\hline Kapanlagi.com & Informed & Diberitakan \\
& Dating Nikita & Kencan dengan \\
& Mirzani, Dhani & Nikita Mirzani, \\
& Reported & Dhani Lapor \\
& Online Media to & Polisi. \\
& Police. & \\
\hline
\end{tabular}

In the first title, the sentence is written in an active form. The subject (Ahmad Dhani) and the object (Online Media) are presented in the text. Meanwhile, the second title is written in a passive form. A passive sentence shows that 
the point of interest is to communicate the occurrence of a date with Nikita Mirzani. The highlight is no longer Ahmad Dhani as the one who reported the online media to the police, but rather the incident, which in the end leads him to go against the news. In a passive structure, the object is placed as a subject, that the subject (in an active sentence) is merely additional. Thus, it concludes that the focus of attention in the first media is that the online media commit a crime, while the second media emphasizes more on the incidents of Ahmad Dhani reported dating with Nikita Mirzani.

\section{Abstraction}

Abstraction strategy is related to whether the information is displayed with a concrete or abstract instruction to obscure information (van Dijk, 2000). The reporter intentionally constructs the abstraction may lead the reader to find a specific impression expected by the media. An event whose participants are quantitatively very small or minor might be described as if it is participated by a vast number of participants through abstraction strategy (van Dijk, 1980).

The example of the use of this strategy upon writing the news related to celebrity prostitution is provided in the following news released on September 22, 2016:

Table 3. The use of abstraction in the news title.

\begin{tabular}{|c|c|c|}
\hline Media & $\begin{array}{l}\text { Translated } \\
\text { Title } \\
\end{array}$ & Original Title \\
\hline Liputan6.com & $\begin{array}{l}\text { Robby Abas } \\
\text { reveals } \\
\text { Shinta's } \\
\text { Dating Rate is } \\
\text { IDR } 50 \\
\text { Million. }\end{array}$ & $\begin{array}{l}\text { Kata Robby } \\
\text { Abas, Tarif } \\
\text { Kencan } \\
\text { Shinta Bachir } \\
\text { Rp 50 Juta. }\end{array}$ \\
\hline Kapanlagi.com & $\begin{array}{l}\text { Robby Abas } \\
\text { Reveals that } \\
\text { The Price of } \\
\text { Shinta Bachir } \\
\text { is the Most } \\
\text { Expensive. }\end{array}$ & $\begin{array}{l}\text { Robby Abas } \\
\text { Ungkap Harga } \\
\text { Jual Sinta } \\
\text { Bachir Paling } \\
\text { Mahal }\end{array}$ \\
\hline
\end{tabular}

Of the two titles, the news in Kapanlagi.com is more abstract than the one in Liputan6.com. The second media creates the impression that the price or rate for the related celebrity is the highest among others involved, while the first media describes her rate as much as the number in the news headline. Delivering something abstractly such as the word "the most expensive," the reader will think differently compared to the use of the exact word with precise information. The other media does not mean they do not know the "exact rate" of Sinta Bachir, but the word "the most expensive" is used to describe her from the lousy point of view, as a celebrity with dirty jobs. Readers will then judge if her wealth is not made through his work in the entertainment, but rather due to her side job in prostitution.

\section{Nomination and Categorization}

Nomination and categorization are textual strategies used to present a person or group of people as to what they are or to assign him a particular attribute or category. Eriyanto (2009: 182) asserted that the form of the category varies by showing essential characteristics such as religion, status, or physical appearance.

The use of nomination and categorization is presented the following example:

Table 4. The use of nomination and categorization in the news title.

\begin{tabular}{lll}
\hline Media & $\begin{array}{l}\text { Translated } \\
\text { Title }\end{array}$ & $\begin{array}{l}\text { Original } \\
\text { Title }\end{array}$ \\
\hline Liputan6.com & Accustomed to & Biasa \\
& Wearing a Sexy & Berpakaian \\
& Dress, the & Seksi, Kok Artis \\
& Actress AA Pakai \\
& shockingly ke \\
& Wears Purdah & Cadar Pengadilan? \\
& to the Court & \\
\hline Kapanlagi.com & Coming to Court & Datangi \\
& of RA, the Actress & Sidang \\
& AA Wears Robe & Mucikari RA, \\
& and & Artis AA \\
& Black Purda & Pakai Gamis \\
& & dan Cadar \\
& & Hitam \\
\hline
\end{tabular}

Both news titles show that the use of categorization as a strategy is not very important because a change in meaning is not found. For example, the omission of the category in the first title," Biasa Berpakaian 
Seksi" does not change the meaning intended to report the fact that the actress AA goes to the court. The current category provision also does not add any information about who the celebrity is. Media can write "Artis AA Pakai Gamis dan Cadar Hitam," yet adding a category of the celebrity may lead to a different impression of the readers. The news indirectly impresses the reader's mind that the celebrity is associated with sexy and open dress. Such news may also lead the reader to furious because the case of the celebrity is prostitution while she wears a robe and veil, which in some cultural constructions they are Muslim's dress. The second title does not take this into account, yet the first title is clear that the media also includes an emotive element upon reporting her dressing style.

\begin{tabular}{|c|c|c|}
\hline $\begin{array}{l}\text { Nominat } \\
\text { ion }\end{array}$ & Celebrity with initials AA & $\begin{array}{l}\text { Came to } \\
\text { the Court }\end{array}$ \\
\hline \multirow{3}{*}{$\begin{array}{l}\text { Categor } \\
\text { ization }\end{array}$} & $\begin{array}{l}\text { Celebrity with initials AA who } \\
\text { used } \\
\text { to wear a sexy dress }\end{array}$ & $\begin{array}{l}\text { Came to } \\
\text { the Court }\end{array}$ \\
\hline & $\begin{array}{l}\text { Celebrity with initial AA } \\
\text { wearing } \\
\text { Veil }\end{array}$ & $\begin{array}{l}\text { Came to } \\
\text { the Court }\end{array}$ \\
\hline & $\begin{array}{l}\text { Celebrity with initial AA } \\
\text { wearing a } \\
\text { robe }\end{array}$ & $\begin{array}{l}\text { Came to } \\
\text { the Court }\end{array}$ \\
\hline
\end{tabular}

\section{Nomination-Identification}

The identification strategy is used to define something. The identification process is done by using clauses as a modifier (van Dijk, 2009). This modifier provides a specific impression or meaning because it is generally a judgment over a particular person, group, or action. According to Eriyanto (2009: 184-185), identification is a discourse strategy where a person, group, or action is reported from the wrong point of view so that the information leads into the readers' lousy impression. The news related to celebrity prostitution on May 11,2016 , shows the use of identification with a particular intention.

Table 5. The use of identification in the news title.

\begin{tabular}{lll}
\hline Media & Translated Title & Original Title \\
\hline Liputan6.com & Robby Abbas & Robby Abbas Sebut \\
& Mentions the & Tarif \\
& Dating Rates of & Kencan Tyas \\
& Tyas Mirasih & Mirasih \\
\hline Kapanlagi.com & Being asked & Ditanya Tentang \\
& about the Rate of & Tarif Tyas, Robby \\
& Tyas, Robby & Abbas: Lupa, \\
\hline
\end{tabular}

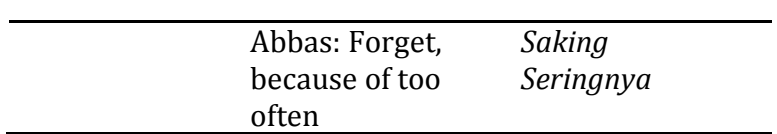

Both articles provide information to the public about Robby Abbas (RA), who mentions the rates for the related celebrity. The exciting part is that additional information is found in the second headline, which shows the direct opinion of RA, "Robby Abbas: Forgot, because of too often." The clause describes the actress (Tyas Mirasih) as an actor who has a busy schedule, thus the impression of public is that the celebrity often gets "the job" from RA. The existence of explanatory sentences does not have a significant influence on the meaning of the sentence explaining that RA speaks up regarding Tyas' rate. The use of this clause is not merely an addition of subjective information about what has been reported but rather the identity or label of the actress. Thus, it concludes that the second title indirectly impresses the readers with the celebrity issue of prostitution.

Another example using this strategy can be found in the news discussing the case of Marshanda.

Table 6. The use of identification in the news title.

\begin{tabular}{|c|c|c|}
\hline Media & Translated Title & Original Title \\
\hline Liputan6.com & $\begin{array}{l}\text { Revealed! Mentally } \\
\text { Ill, Marshanda does } \\
\text { not Breastfeed her } \\
\text { Daughter }\end{array}$ & $\begin{array}{l}\text { Terungkap! Sakit } \\
\text { Kejiwaan, } \\
\text { Marshanda Tak } \\
\text { Beri Anak } \\
\text { ASI }\end{array}$ \\
\hline Kapanlagi.com & $\begin{array}{l}\text { Marshanda cannot } \\
\text { Breastfeed the } \\
\text { Daughter; Ben } \\
\text { Kasyafani is } \\
\text { Considered Cruel }\end{array}$ & $\begin{array}{l}\text { Marshanda Tak } \\
\text { Bisa } \\
\text { Menyusui Anak, } \\
\text { Ben Kasyafani } \\
\text { Dinilai Kejam }\end{array}$ \\
\hline
\end{tabular}

The meaning of the first and second sentences, even if without explanatory clause such as "Terungkap! Sakit Kejiwaan," and "Ben Kasyafani Dinilai Kejam," will not change. The sub-clause in the first headline serves as an explanation and provides a negative image to Marshanda. She is reported that she does not breastfeed her daughter due to mental illness, and has to take drugs, that it is dangerous if she gives breastfeed. Moreover, the subclause also informs the public that Marshanda does not deserve to be a mother because a mother must breastfeed her daughter. Implicitly, it also affects the reader's 
perception of the divorce between Marshanda and Ben, which can be attributed to the previous example that Marshanda, who is eager to divorce, turned out to have a mental disorder that she refuses to call for reconciliation from Ben.

In contrast to the second news title, the clause serves as explanatory and gives a negative image of Ben. Ben is reported cruel because it is associated with the condition of Marshanda, who could not breastfeed his daughter. Also, readers will feel that Ben is indeed a father who has no compassion for letting his daughter not be breastfed by the mother. The title of this news also implicitly leads the readers to assume that what Ben has done so far (his effort to fix his relationship with Marshanda) is merely an image.

In both news titles, the sub-clauses do not change the meaning of the news headline because it reports that Marshanda does not do breastfeeding. On the contrary, in the other news, Marshanda could not breastfeed her daughter. The use of the sub-clause is an explanation of how the media convey meaning and lead public opinion through the news. In addition to the use of identification strategy, the other news also uses the passivation strategy in Ben Kasyafani is considered cruel. The focus of the attention of the reader is only on the fact that Ben is cruel as a father, while the actor/subject is wholly omitted from the news. Who judges and on what basis Ben is considered cruel is not the focus of the news under this sentence construction because it leads the readers to only look at the object (Ben's cruelty), not the doer who gives the judgment.

\begin{tabular}{ll}
\hline Nomination & $\begin{array}{l}\text { Marshanda did not breastfeed } \\
\text { her daughter }\end{array}$ \\
\cline { 2 - 2 } & $\begin{array}{l}\text { Masrhanda could not breastfeed } \\
\text { her daughter }\end{array}$ \\
\hline $\begin{array}{l}\text { Identificatio } \\
\mathbf{n}\end{array}$ & $\begin{array}{l}\text { Mentally Ill, Marshanda did not } \\
\text { breastfeed her daughter }\end{array}$ \\
\cline { 2 - 2 } & $\begin{array}{l}\text { Marshanda could not breastfeed } \\
\text { her daughter; Ben Kasyafani } \\
\text { was considered cruel }\end{array}$ \\
\hline
\end{tabular}

Anonymity

News about certain events or actors is sometimes explicitly mentioned, but it is also unclear sometimes. Anonymity, according to van Leeuwen (1987), may lead to generalization. The use of this discourse strategy is found in the news related to Marshanda's action involving her daughter (Sienna) during a meeting with her affair.

Table 7. The use of anonymity in the news title.

\begin{tabular}{lll}
\hline Media & $\begin{array}{l}\text { Translated } \\
\text { Title }\end{array}$ & Original Title \\
\hline Liputan6.c & Ben is & Ben Kesal \\
om & Angry, & Marshanda Ajak \\
& Marshanda & Anak Saat Bertemu \\
& Invites her & Selingkuhan \\
& Daughter & \\
during & \\
& Meeting her & \\
& Affair & \\
\hline Kapanlagi. & Ben does & Ben Tak Ingin \\
& not Want & Sienna \\
& Sienna & Dipertemukan \\
& meet & Dengan \\
& Marshand & Selingkuhan \\
& a's Affair & Marshanda \\
\hline
\end{tabular}

The first media anonymously writes the daughter of the celebrity couple and another one who is deemed to be Marhanda's affair. On the contrary, the second media writes the subject involved (Sienna) but still called the affair anonymously. When the name is mentioned, the meaning of the sentence becomes more specific, but if they use "daughter" or "affair," the meaning is unclear. In the other media, Sienna's object is visible because it appears specifically, while that in the first media is not clear because it is presented anonymously. It causes the readers' focus on the other media to Sienna object, while in the first media, they focus on Marshanda because the object is written anonymously. Besides, the first and second media also writes an affair together anonymously. The anonymity occurs because the news writers do not know or could be due to the structural fears that cause the media to stand by obscuring one of the people involved in the news. The media which states Marshanda is guilty will likely blur or use anonymity when someone else is involved in the news that corners Marshanda. However, the media which considers Marshanda innocent will mention the other parties involved and eliminated to mention Marshanda herself on the same news.

Table 8.The use of anonymity in the news title

$\begin{array}{lll}\text { Media } & \begin{array}{l}\text { Translated } \\ \text { Title }\end{array} & \text { Original Title } \\ \end{array}$




\begin{tabular}{lll}
\hline $\begin{array}{l}\text { Mentioned } \\
\text { clearly }\end{array}$ & $\begin{array}{l}\text { Marshanda invites Siena to meet Egi } \\
\text { John }\end{array}$ \\
\cline { 2 - 3 } & $\begin{array}{l}\text { Robbi Abbas is abandoned by Amel } \\
\text { Alvi }\end{array}$ \\
\hline $\begin{array}{l}\text { Mentioned } \\
\text { anonymou } \\
\text { sly }\end{array}$ & $\begin{array}{l}\text { Marshanda invites her daughter to } \\
\text { meet her affair }\end{array}$ \\
\cline { 2 - 3 } & RA is abandoned by his celebrity \\
& prostitute. & \\
\hline Liputan6.c & RA Feel & Mucikari RA \\
om & being left & Merasa Habis Manis \\
& behind by & Sepah Dibuang Oleh \\
& Amel Alvi & Amel Alvi \\
& after & \\
& Having Fun & \\
\hline Kapanlagi. & Being Left & Habis Manis Sepah \\
com & after & Dibuang, RA \\
& Having Fun, Ditinggalkan PSK \\
& RA was & Artis-nya \\
& Abandoned & \\
& by His & \\
& Prostitute & \\
\hline
\end{tabular}

The title of the first news clearly shows the initial RA and the name of Amel Alvi on the news title, while the title of the second media wrote the celebrity prostitute anonymously. Thus, if the name or identity is clear, the meaning will become more specific, while if the identity or name is generalized, the meaning will be blur or invisible. As in the previous analysis, this anonymity occurs not because of the ignorance of the media but the "subjectivity" and interest of media. If it is viewed from the subjectivity of the media, the first title will cause a more negative impression to Amel Alvi because the name refers to the one who leaves somebody else after getting a significant profit. In contrast, the second title creates a more negative impression on RA because he has a negative profession, that it is reasonable to receive adverse treatment. Furthermore, if it is viewed from the interest of the media, mentioning Amel Alvi's name can be supposed as marketing because media has a foundation of a name that makes the news. If an ordinary person works as a prostitute, it is not considered as news, yet if the celebrity does the same thing (being a prostitute), it is news.

\section{CONCLUSION}

Related to how actors/events are displayed in the news text, van Dijk's framework covers three main dimensions, macro-structure, superstructure, and microstructure. In this research, the researcher focuses on the microstructure of the news text related to celebrities in several online media. It is also limited to the selection of specific vocabulary and grammar used by the media upon reporting certain actors or events related to Indonesian celebrity. The media tends to use different words to describe parties that are considered part of "us" or who are considered as "them." In an interfaith marriage, for example, the media tend to use words with a negative connotation to describe parties from minority religions. In divorce cases, the media also uses certain words that only blame the woman's side. The use of ideological word choice is also found in celebrity prostitution news. The media seems only expose the women in detail, not with men. Besides the use of lexicalization on celebrity news in online media, it is also found that media uses particular grammar comprising of activation and passivation, abstraction, categorization, identification, and anonymity. The use of this strategy does not solely aim to communicate the content of the news but to influence the view of public/readers. They are invited by the media to think and make specific prejudice, not the others.

\section{REFERENCES}

Allan, Keith and Kate Burridge. 2006. Forbidden Words: Taboo and the Censoring of Language. New York: Cambridge University Press.Austin, Brent John. 2014. "CELEBRITIES, DRINKS, AND DRUGS: A CRITICAL DISCOURSE ANALYSIS OF CELEBRITY SUBSTANCE ABUSE AS PORTRAYED IN THE NEW YORK TIMES". Electronic Theses, Projects, and Dissertations. Paper 104.

Barrat, David. 1994. Media Sociology. London: Routledge.

Bogdan, Robert and Sari Knopp Biklen. 1988. Qualitative Research in Education. USA: Allyn \& Bacon. 
Darma, Yoce Aliah. 2009. Analisis Wacana Kritis. Bandung: YramaWidya. Eriyanto. 2000. Kekuasaan Otoriter: dari Gerakan Penindasan Menuju Politik Hegemoni (Studi atas Pidato-pidato Politik Soeharto). Yogyakarta: Insist.

Eriyanto. 2009. Analisis Wacana: Pengantar Analisis Teks Media. Yogyakarta: LKiS.

Eriyanto. 2009. Analisis Framing. Yogyakarta: LKiS.

Hall, Stuart. 1982. The Rediscovery of Ideology: Return of the Repressed in Media Studies. Dalam Gurevitch, M., et al. (ed.), Culture, Society and the Media. London: Methuen. 1982. Hlm. 67.

Irsyadi, Achmad Naufal. 2019. Gaya Wacana Media dalam Konstruksi Media tentang Pemberitaan Elektabilitas Presiden. Lingua Journal of Linguistics and Literature, vol.14, No.1, June 2019, pp. 197 - 204. Malang: Faculty of Humanities Universitas Islam Negeri Maulana Malik Ibrahim.

Kabgani, Sajad. 2013. The Representation of Muslim Women in Non-Islamic Media: A Critical Discourse Analysis Study on Guardian. International Journal of Women's Research, Vol.3, No.1, Spring 2013, pp. $57-78$.

Kesuma, Tri Mastoyo Jati. 2007. Pengantar (Metode) Penelitian Bahasa. Yogyakarta: Carasvati books.

Leeuwen, Theo van. 1987. "The Representation of Social Actors". in Carmen Rosa Caldas-Coulthard and Malcolm Coulthard (ed.), Text and Practices: Readings in Critical Discourse Analysis. London and New York: Routledge.

Miles, B., Matthew, and Huberman, A, M. 1994.Qualitative Data Analysis: a sourcebook of new methods. California: Sage.

Rahardjo, Mudjia. 2007. Hermeneutika Gadamerian: Kuasa Bahasa dalam Wacana Politik Gus Dur. Malang: UIN-Malang Press.

Rahayu, Mundi, Irwan Abdullah and Wening Udasmoro. 2015. "Aladdin" from Arabian Nights to Disney: the Change of Discourse and Ideology. Lingua Journal of Linguistics and Literature, vol.10, No.1, June 2015, pp. 24 - 34. Malang: Faculty of Humanities Universitas Islam Negeri Maulana Malik Ibrahim.

Richardson, John E. 2007. Analyzing Newspaper: An Approach from Critical Discourse Analysis. New York: Palgrave Macmillan.

Rosidi, Sakban. 2007. "Analisis Wacana Kritis sebagai Ragam Paradigma Kajian Wacana (Critical Discourse Analysis as Variance of Paradigm of Inquiry on Discourse)". Unpublished article. Malang: UIN Malang.

Sobur, Alex. 2012. Analisis Teks Media. Bandung: PT Remaja Rosdakarya.

Soares, Leonardo Antonio. 2017. Analysis of Super Noticia Popular Newspaper Through A Critical And Multimodal Perspective. v.61, n.3, p.657-679. Sao Paulo: Alfa.

Stubbs, Michael. 1989. Discourse Analysis: The Sociolinguistics Analysis of Natural Language. Oxford: Basil Blackwell.

Susanto, Eko Harry and Silviana Dharma Zhang. 2017. Critical Discourse Analysis of Interfaith Marriage News from Cyber Media in Indonesia. Journal of Educational and Social Research (JESR). Rome: De Gruyter. 
Van Dijk, Teun A. 1980. Macrostructures: An Interdisciplinary Study of Global Structures in Discourse, Interaction, and Cognition. Hillsdale. New Jersey: Lawrence Erlbaum Associates.

Van Dijk, Teun A. 1997. News as Discourse. Hillsdale. New Jersey: Lawrence Erlbaum Associates.

Van Dijk, Teun A. 2000. Ideologies, Racism, Discourse: Debates on Immigration and Ethnic Issues.

Van Dijk, Teun A. 2000. The Reality of Racism: On Analyzing Parliamentary Debates on Immigration.

Van Dijk, Teun A. 2003. Ideology and Discourse: A Multidisciplinary Introduction. Internet Course for the Oberta de Catalunya (UOC).

Van Dijk, Teun A. 2004. "From Text Grammar to Critical Discourse Analysis". Working Paper. Vol.2. Barcelona: Universitat Pompeu Fabra.

Van Dijk, Teun A. 2009. Society and Discourse: How Social Contexts Influence Text and Talk. Cambridge: Cambridge University Press. 